\title{
RESIDENTIAL EARTHEN ARCHITECTURE IN MULA (SPAIN): STUDY AND CATALOGUING OF ITS CONSTRUCTION TECHNIQUE
}

\author{
F. J. López Martínez ${ }^{1}$, V. La Spina ${ }^{2,}$ *, J. Fernández del Toro ${ }^{3}$ \\ ${ }^{1}$ Universidad Católica San Antonio de Murcia, Spain - fjlopez@ucam.edu \\ ${ }^{2}$ Universidad Politécnica de Cartagena, Spain - vincenzina.laspina@upct.es \\ ${ }^{3}$ Ayuntamiento de Mula, Murcia, Spain - juanfdt@gmail.com
}

Commission II - WG II/8

KEY WORDS: Residential habitat, Earthen architecture, Construction techniques, Mula

\begin{abstract}
:
The city of Mula (Region of Murcia, Spain), of Islamic origin and built on the top of a hill, is dominated by the spectacular Renaissance castle of Velez and a mediaeval defensive wall. The wall remains, those still standing, consist of several enclosures and sections built in rammed earth. As many of these are a magnificent example of defensive earthen architecture, the Castle of Mula has been widely analysed and recently protected by a Master Plan. However, Mula's unique old town, an Asset of Cultural Interest in the category of Historic-Artistic Complex, with its irregular and narrow streets at the foot of the castle, includes residential constructions (mansions, palaces and humble dwellings) made with earth. The traditional residential architecture of Mula includes characteristic 2or 3-storey buildings with sloping roofs. However, there are no specific studies on these and the use of earth as a construction material. The main aim of the study therefore is to carry out an initial identification and cataloguing of the different earthen construction techniques in the historic residential buildings of the old town and their relation to the residential typology of Mula.
\end{abstract}

\section{INTRODUCTION}

\subsection{Brief historical-geographical description of Mula}

The municipality of Mula, measuring $633 \mathrm{~km}^{2}$, in the centre of the Region of Murcia (Spain) is the sixth largest in the region (Figure 1). Its territory is semiarid and local flora and fauna adapt to the water scarcity. The city of Mula was a key location of the Treaty of Tudmir in the year $713 \mathrm{AD}$, when the Visigoths handed over their most important cities in exchange for a peace settlement with the Moors, respecting Visigothic customs and religion (Molina, 1995). However, the Late Roman Mula was located in Cerro de la Almagra, beside the district of los Baños de Mula. For reasons unknown, the original city was destroyed circa 825 AD (González, Fernández, 2010) and its population resettled elsewhere. One of these settlements was the new Mula, which at the time was probably a small hamlet of little political influence, despite its strategic importance under the shelter of a hisn (similar to a feudal castrum). Due to its situation overlooking the pass between the newly founded capital of Murcia and the northwest and its fertile plain, the importance of Mula in the southeast of the Peninsula grew until it became a madina. So much so that it became the capital of a large iqlim (district), covering a large part of what is now the Region of Murcia (González, 1992).

The new city was built high on the southern slope of a hill, barely $4 \mathrm{~km}$ from its original location. Throughout the Middle Ages the urban layout was delimited by the three walled complexes defending the population (Collado et al., 2018). The lower complex, the medina, housed all residential buildings and any other buildings where the population carried out daily activities.
In addition, the orchard was divided into strips running downhill and irrigated by the waters of the Acequia Mayor.

Over centuries the urban development of the limited space between the walls and the craggy terrain gave rise to a labyrinth of buildings, with narrow streets which were often dead ends. The network of steep streets, which ran from east to west, followed the contour lines, adapting to the different levels and also used for water runoff. There are barely any open spaces in the area, with the exception of the plaçuela bieja (Fernández, 2018) which was probably used as a main square until construction of the current one in the $1520 \mathrm{~s}$.

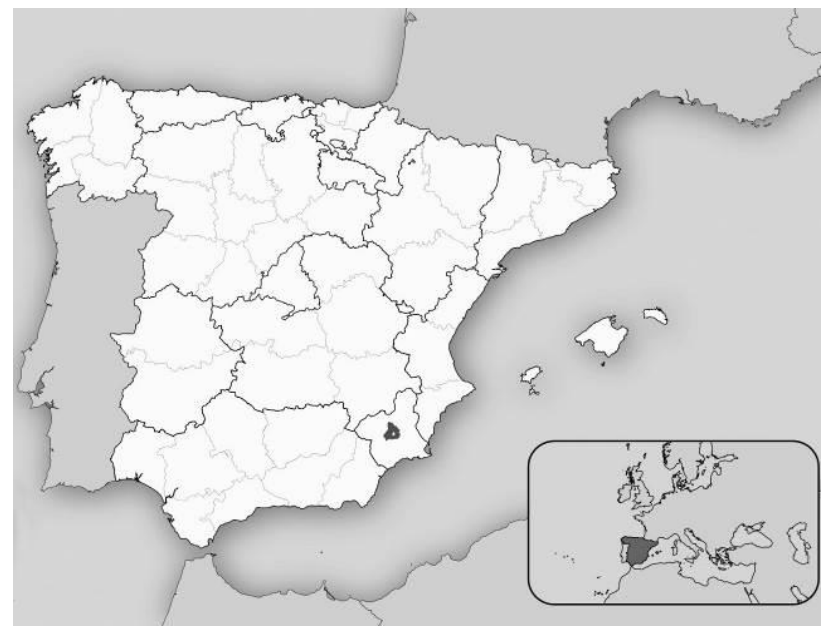

Figure 1. Map showing the location of Mula in the Region of Murcia and Spain (Source: Wikipedia and authors)

\footnotetext{
* Corresponding author
} 


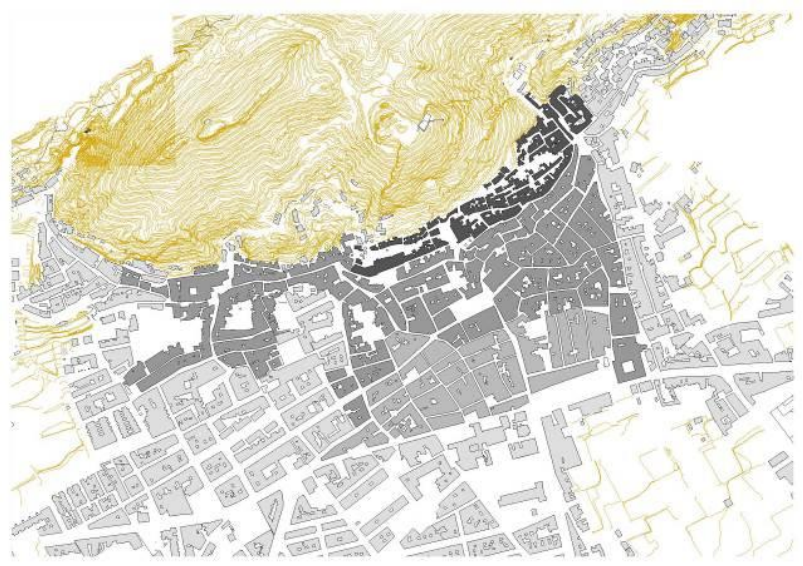

Figure 2. City plan of Mula showing the three main areas of Mula shaded: Mediaeval (black), 16th c. (dark grey) and 18th c. (light grey) (Source: Ródenas, 1991 and authors).

With the conquest of the Kingdom of Granada in 1492 there was no longer a risk of attack from Nasrid troops, so that Mula was able to remove its defensive wall. At this point an initial urban expansion took place, and the population grew. However, the buoyant economy of the 16th century gave way to a severe economic crisis in the city in the 17th century (González, 1983), and no new urban development took place until well into the 18 th century (Figure 2).

In geological terms, the municipality of Mula sits on layers of sediment transported by the river Mula to form marlstone covered with a layer of limestone or gypsum. Therefore, lime and gypsum were used as construction materials, as has the reddish calcareous Almagra stone, which was already quarried in Roman times (Soler, 2005). In contrast, the vegetation is that characteristic of Mediterranean areas with dry summers. Oaks and plantations of pine trees are plentiful, together with fertile orchards alternating with steep karst landscapes devoid of vegetation (González, 1990).

Finally, it should be noted that Mula is in a high-seismic risk area, which has experienced earthquakes on different scales at different points in history. The 1999 earthquake affected historic buildings to different degrees.

\subsection{Residential architecture in Mula: description and typologies}

The different periods in the city's history have led to the configuration of the historic city centre (declared Asset of Cultural Interest in the category of Historic Complex at National level in 1981) where the different construction stages can be identified. There is little residential architecture in the upper section where the mediaeval neighbourhoods are located. It follows the rugged terrain, with a very basic system of traditional: rammed earth walls (probably linked to the Moorish building culture heritage). This features floors and ceilings with round pine $\log$ s and gypsum beam fills, and sloping roofs with curved ceramic tiles set on reeds resting on rounded logs (Figure 3). The existence of cave homes should also be mentioned.
The 16th-century urban expansion brought about large open spaces for construction, contrasting with the overcrowded mediaeval neighbourhoods. This new area saw the construction of first palaces or mansions for the city's noble families (Figure 4). Thus, large imposing one- and two-storey palaces were built, adjoining big orchards. In some cases, it is worth highlighting the decorative alfiz doorways found on some of the main façades of many homes following the Mudejar tradition.

After the economic and demographic crises, some new palaces were built throughout the 18th century as part of an initial urban development. In other cases the most important families established their residences in 16th-century palaces they had inherited (González, González, 2005). In most cases they respected the alfiz doorways mentioned above, while the rest of the building was rebuilt and its layout reconfigured. The ground floor was used by servants; the first floor by the family; and a cellar was added for wine, oil, and vinegar, while the rooms on the top floor were used to store wheat crops and cured meats (Figure 5). Brick was predominantly used for load-bearing walls and combined with masonry or rammed earth. Curved ceramic roof tiles, traditional in the area, continued to be used on the roof. The façades were decorated with family coats of arms and occasionally sgraffito.

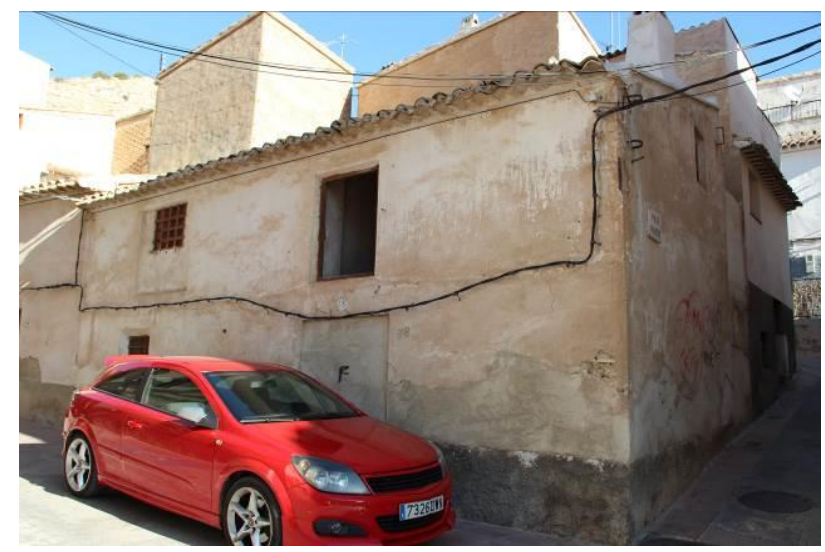

Figure 3. Humble dwelling in the upper area of Mula (Source: authors).

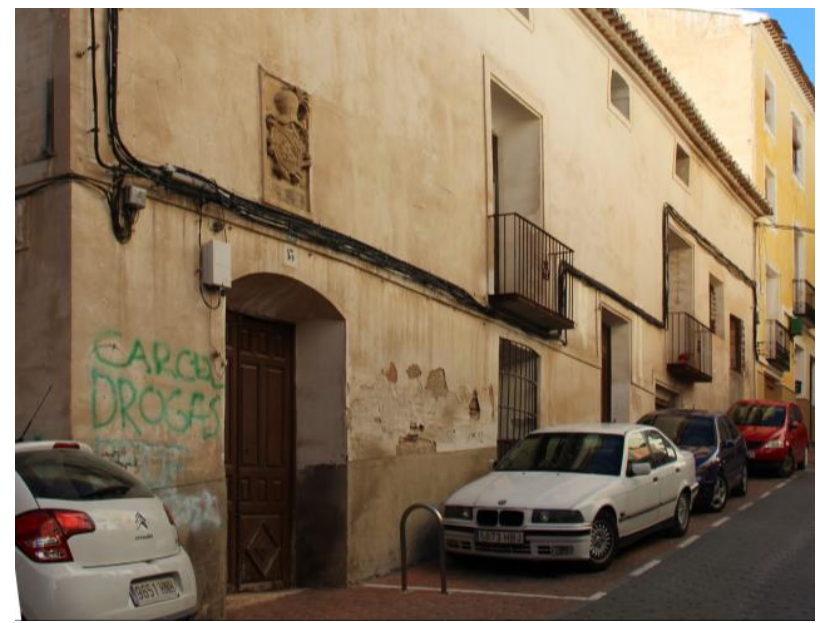

Figure 4. 16th-century palace in Mula (Source: authors). 


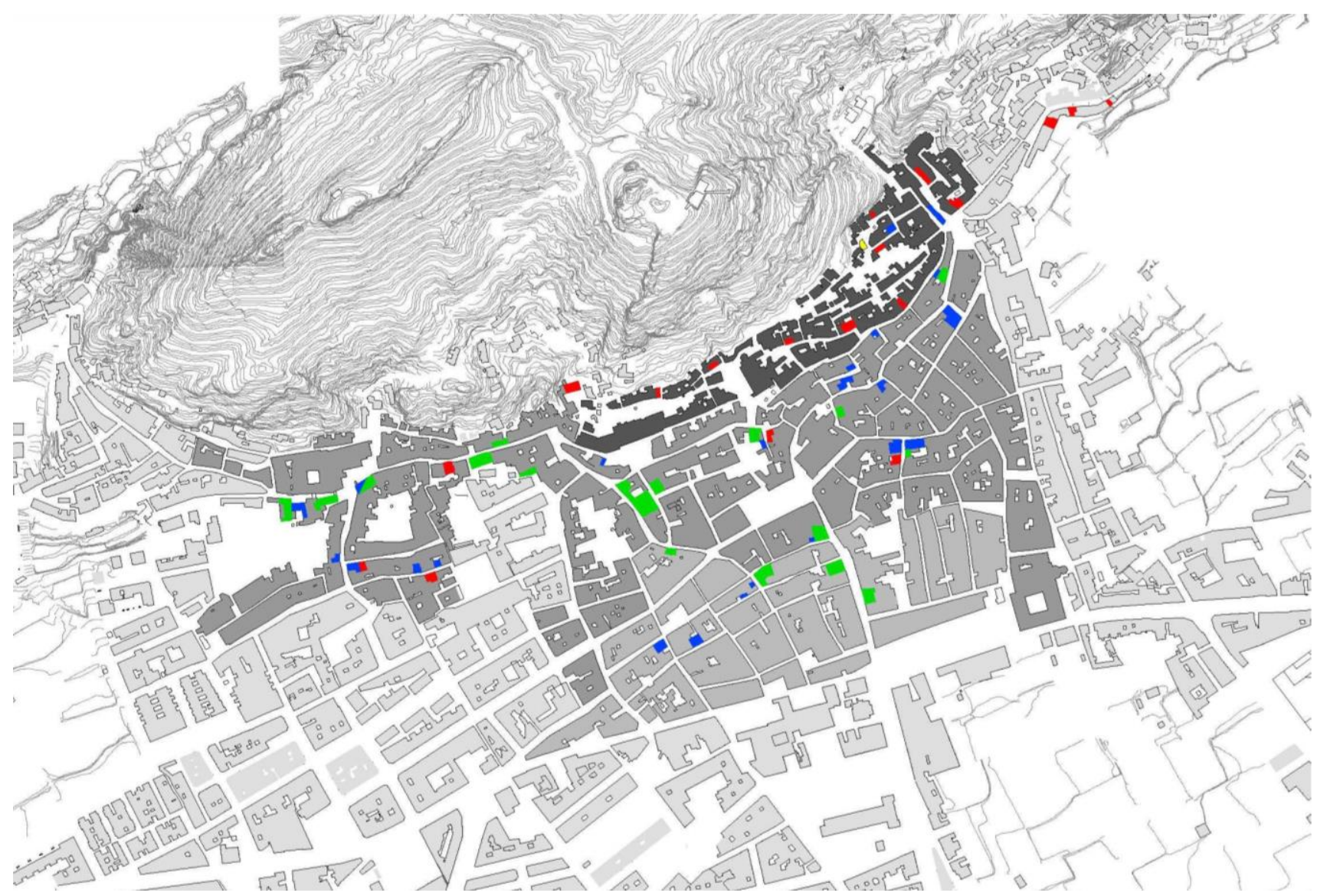

Figure 6. Plan showing the buildings included in the study (Red: simple rammed earth; Blue: Supplemented rammed earth; Green: mixed rammed earth and Yellow: dug-out) (Source: authors).

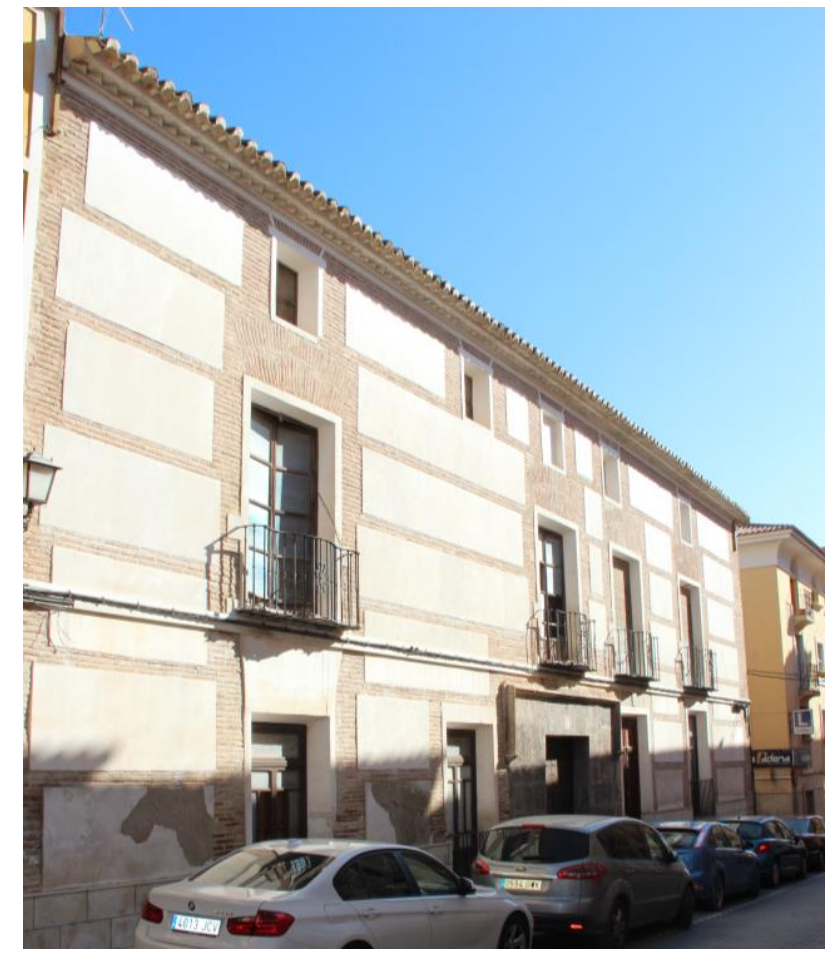

Figure 5. 18th-century palace in Mula (Source: authors)

\section{RESEARCH AIM AND METHODOLOGY}

The main aim of this article is to draw attention to earthen residential architecture in the historic town centre of Mula (Murcia, Spain) based on the typological identification and descriptions of the different construction techniques used. The analysis focuses exclusively on the city's historic residences in different areas of expansion at the foot of the castle: mediaeval quarters from 16th and 18th centuries. Some of these also fall within the scope of the castle and medina as detailed in the Master Plan for the Castle of Mula (Murcia) (Bestué, 2018) (Figure 6).

The research methodology was divided into several phases, examining different bibliographical and archival sources, as well as the local residential architecture itself. The initial fieldwork carried out consisted in cataloguing and drawing up an inventory of approximately 70 buildings, using the templates defined for the research project SOStierra "Restoration and rehabilitation of traditional earthen architecture in the Iberian Peninsula. Guidelines and tools for a sustainable intervention", funded by the Spanish Ministry of Science and Innovation (Ref: BIA2014-55924-R; main researchers: Camilla Mileto and Fernando Vegas López-Manzanares). For this project there were various visits to Mula in January 2020, with three researchers taking part, always in collaboration with Town Council specialists and local residents. 
All the information compiled was then analysed and classified, identifying common features among the results, as well as specific features mostly associated with building typologies, construction techniques used and building location within the city's historic layout (Mileto et al., 2011a, 2011b, 2012).

Therefore the main sources for this research were the earthen buildings themselves. However, in many cases, existence of elements altering the façades, including renderings or recent coats of paint, the repair of superficial detachments, or openings added to the façades has been a continual hindrance to the study. Another limitation was the impossibility of carrying out complete observations of construction elements. For instance, when analysing the exterior surface of a wall it would have been useful to also be able to analyse its section or most deteriorated points, corners, joints, etc., as well as accurately identifying the materials. This is why in many cases the information gathered is considered to be partial and subject to potential reformulations or interpretations. In spite of this, it should be stressed that dividing walls are not generally rendered, and so become essential elements in accurately deciphering the rammed earth wall typology used in the construction of a building.

\section{EARTHEN CONSTRUCTION TECHNIQUES IN THE RESIDENTIAL ARCHITECTURE OF HISTORIC MULA}

Initially, the study identified the different earthen construction typologies used in the construction of historic buildings in Mula, as well as their existing location. The main technical specific points were then identified before analysing the state of conservation and repairs undergone over the centuries.

\subsection{Earthen construction typologies}

Most earthen typologies observed in the residential buildings of Mula (Murcia) fall within two major categories: rammed earth and dug-out architecture, following the classification of the framework of different research projects: the European project Terra [In]cognita. Architecture de terre en Europe (20090758/001-001) and the ResTAPIA project, "The restoration of rammed earth architecture in the Iberian Peninsula. Criteria, techniques, results and perspectives" (BIA2010-18921) funded by the Spanish Ministry of Science and Innovation (Mileto et al 2011a, 2011b, 2012, 2014). No adobe houses were found during the fieldwork. Most of the buildings were built in rammed earth, and some presented simple rammed earth walls rendered after the formwork had been removed. In other cases, buildings supplemented rammed earth walls with reinforced surfaces or joints or even mixed rammed earth walls which mostly included small pillars and/or brick courses combined with rammed earth or masonry formwork

3.1.1 Simple rammed earth: The most frequent simple typology found in Mula is rammed earth, found in $27 \%$ of the examples analysed. This was mainly found in the constructions from the mediaeval neighbourhoods. These tend to be rendered, primarily in gypsum, to protect exterior surfaces from erosion and the elements (Figure 7). In the absence of analysis it is not known whether the rammed earth walls were also built using lime, that is to say, whether they are actually a tapia real (Mileto et al., 2014). However, material differences can be observed in the aggregate found in the simple rammed earth walls in Mula, sometimes coarse aggregate of a heterogeneous granulometry, often containing stone, brick or gypsum rubble from demolished or ruined buildings.
3.1.2 Supplemented rammed earth: This typology represents $44 \%$ of the case studies encountered. For the most part these are lime-crusted rammed earth walls, that is to say, rammed earth walls built with a different mix from that used inside the wall (Figure 8). Unfortunately, as the cross-section of this type of rammed earth wall can only be viewed in very few instances (as in the case of the demolished house on calle de las Rejas no. 23 and 25), it is almost impossible to ascertain whether the rammed earth walls only have lime wedges or also incorporate an inner layer throughout the wall's horizontal section. As well as the original surface protection of the rammed earth walls carried out as the wall was being built, they also present continuous rendering added at a later date which seals and hides all possible marks or imperfections of the construction technique.

Another specific example of supplemented rammed earth walls can be found in the building on calle Mizas no. 56 in a rammed earth wall with a gypsum coating, or gypsum-crusted rammed earth wall (La Spina, Grau, 2020). This technique uses a gypsum mortar or paste as a binding agent rather than lime, resulting in a surface where the different tamped layers can be clearly observed (Figure 9).

Some examples of rammed earth incorporating brick in different layers on the surface have also been found, as have rammed earth walls with brick supplements on the joints. These are primarily reinforcements on the horizontal joints in the form of courses usually made up of a row or more, or even courses in the same material, but every second rammed earth block, so that they are not necessarily on all the joints between rammed earth bricks on the same wall.

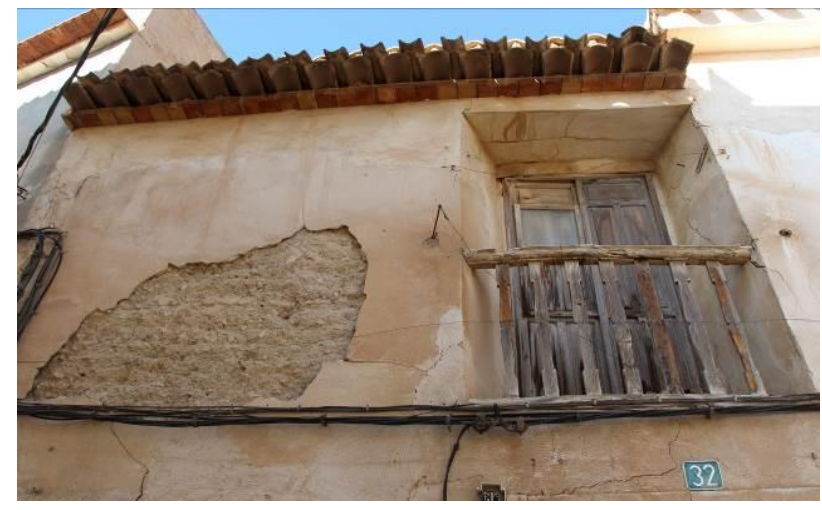

Figure 7. Simple rammed earth wall rendered with gypsum (Source: authors).

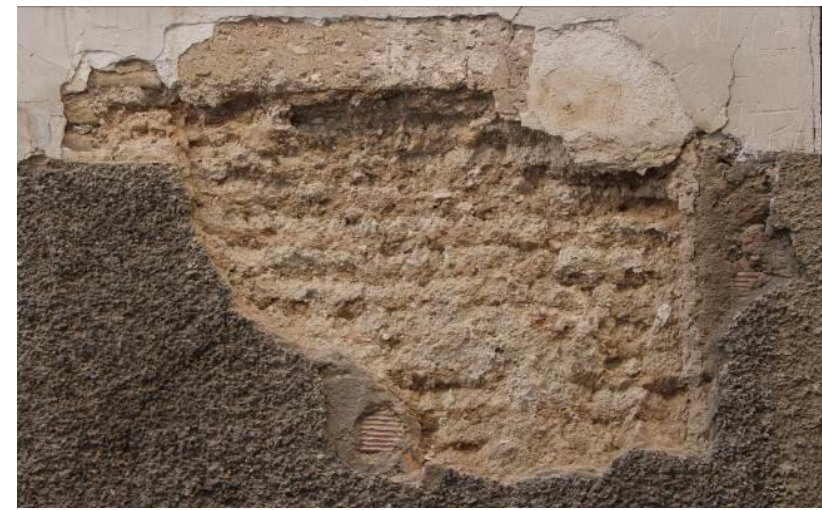

Figure 8. Detail of the lime layers of a lime-crusted rammed earth wall (Source: authors). 


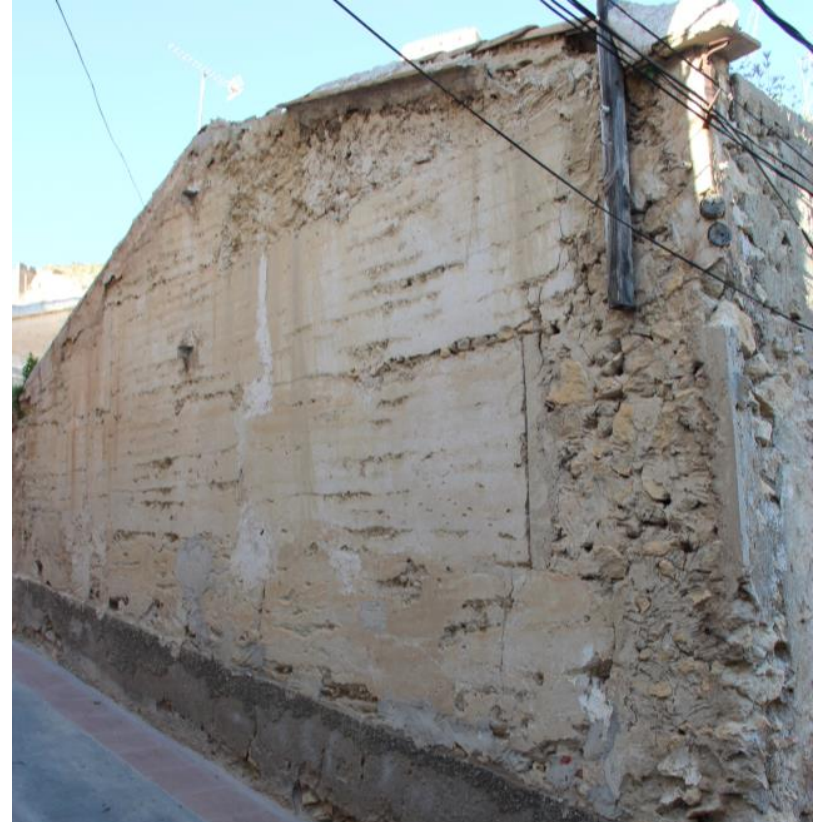

Figure 9. Gypsum-crusted rammed earth wall and gypsum guided masonry pillars (Source: authors).

3.1.3 Mixed rammed earth: In Mula, these rammed earth walls are found in the lower sections of the historic city as seen in the city plan in Figure 6, and were built in the 16th and 18th centuries, accounting for $28 \%$ of the case studies analysed.

The most prevalent mixed rammed earth walls are those combining small brick pillars and brick courses, or incorporating only brick, with simple or supplemented formwork, as well as brick formwork. In addition, the brick constructions occasionally predate the assembly of the rammed earth while at other times they are more recent. As with other rammed earth typologies, the whole surface or the formwork was rendered after execution making it difficult to identify the different possible typologies.

In all cases, to ensure union of the rammed earth the small brick pillars are of different widths on each course, preventing the vertical joints from being in line. They all coincide with doors or window jambs, except when these were added after the rammed earth construction.

3.1.4 Dug-out architecture: In the highest part of the town, at the foot of Mula castle, the sedimentary rock surface is easy to carve out, so there are numerous buildings known locally as casonas. These cave homes are built taking advantage of the steep slope of the land. In most cases small single-storey constructions adjoining the hill are used to access the casón or cave hewn out from the rock (Figure 11). Therefore, some of the rooms in these buildings have daylight and exterior ventilation, while in other cases the houses are carved out with a vaulted roof in a type of construction which frequently has no vertical ventilation (Figure 12).

Only one such construction accessed could be included in the study and was positively identified as a casón. At present there is no complete census of all existing casonas as they are hard to identify, mainly because most are privately owned, except that included in the study, which belongs to the local administration.

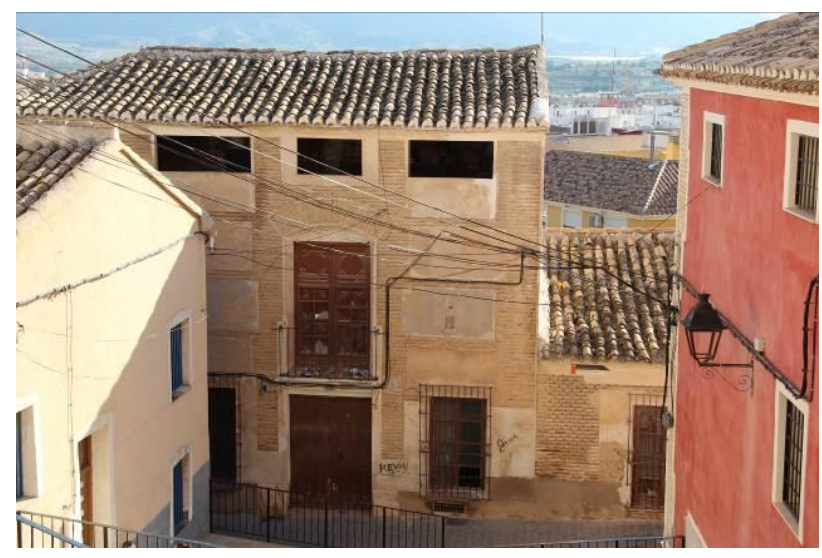

Figure 10. Mixed rammed earth wall in the dwelling on calle Sastres no.7 (Source: authors).

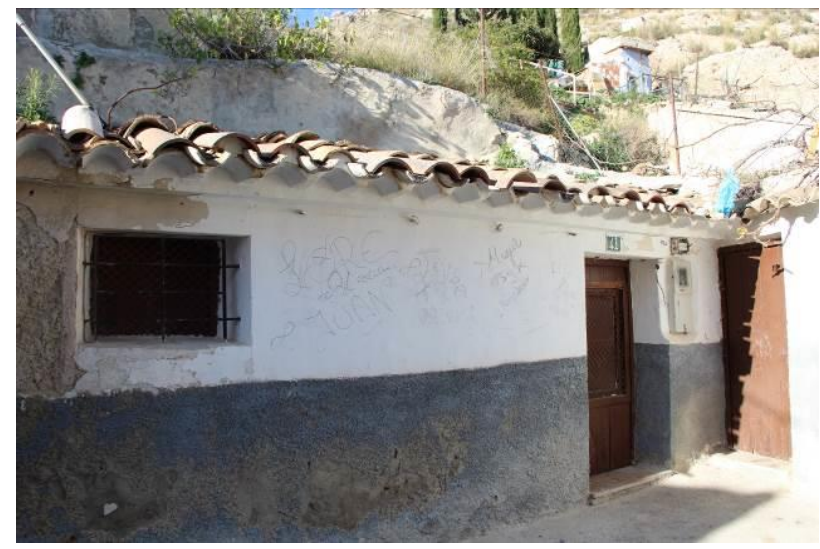

Figure 11. Exterior of the casón on calle Mizas no. 41, exterior and detail of the interior (Source: authors).

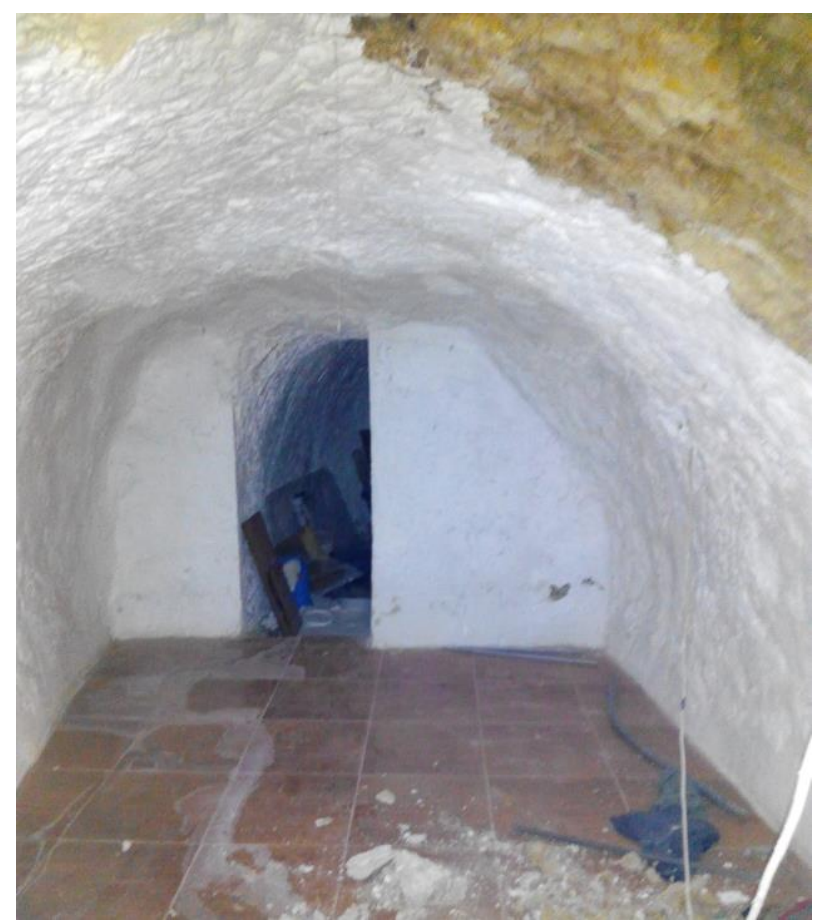

Figures 12. Detail of the interior of the casón on calle Mizas no. 41 (Source: Mula Town Council). 


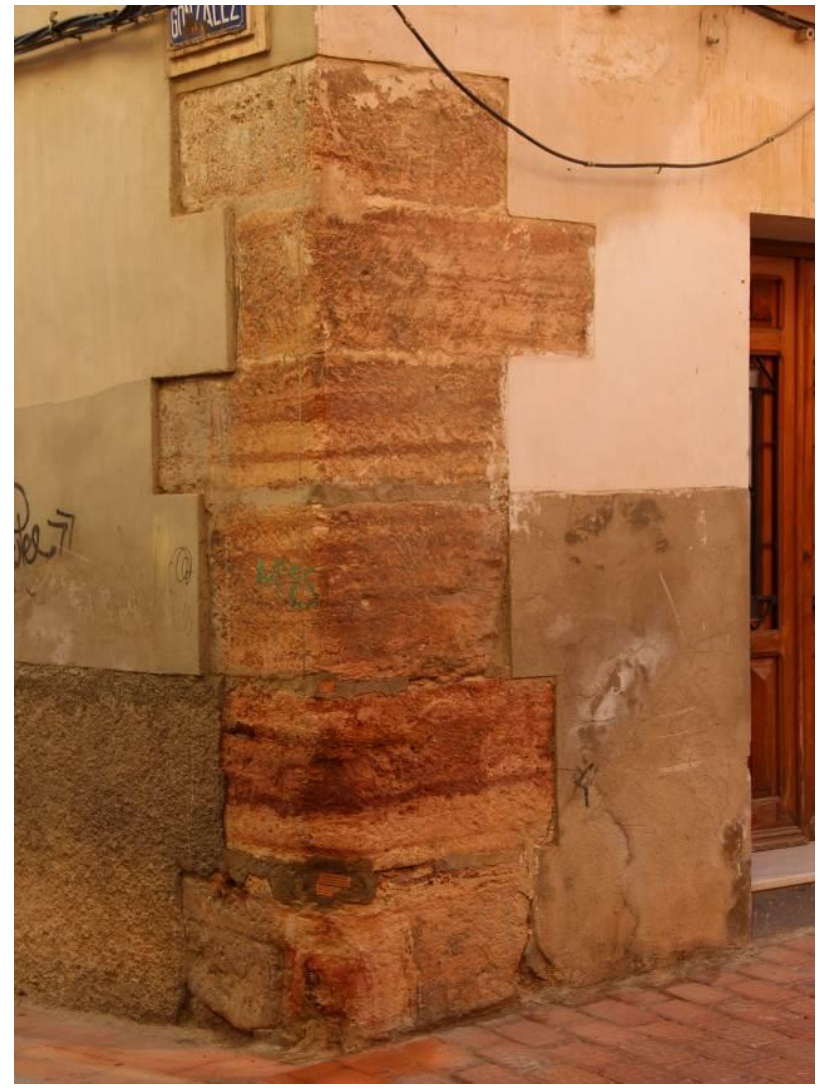

Figure 13. Detail of an Almagra stone corner plinth in Mula (Source: authors).

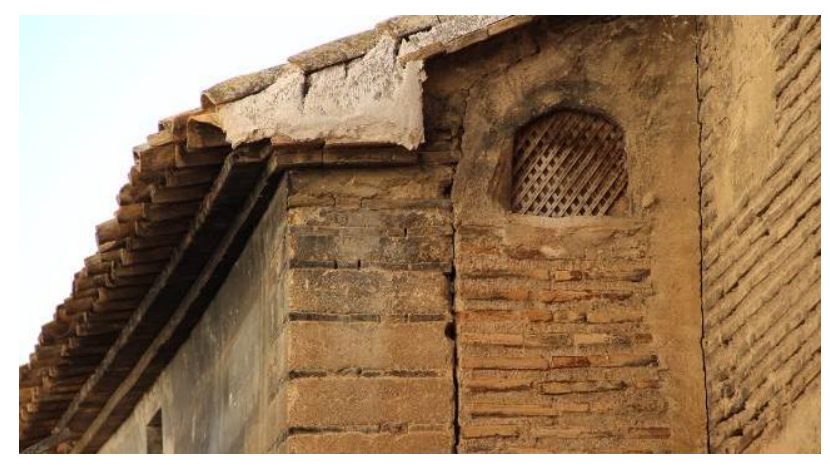

Figure 14. Rammed earth corner supplemented with bricks (Source: authors).

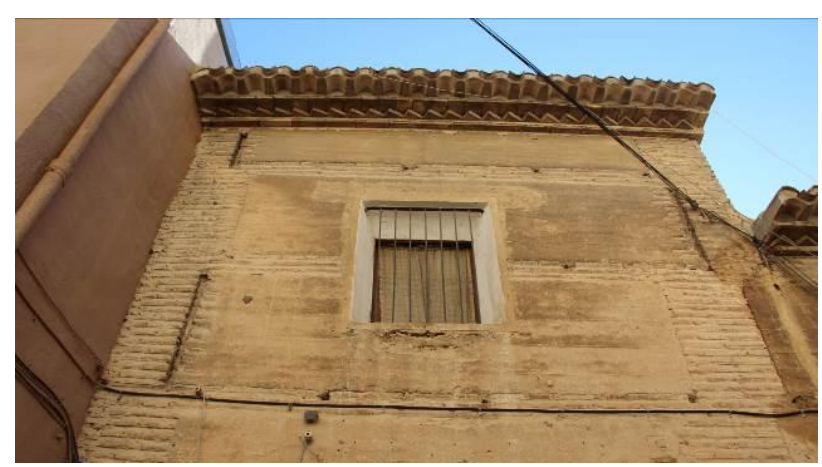

Figure 15. Building on calle Monjas no. 54 (residence within the Real Monasterio de la Encarnación) (Source: authors).

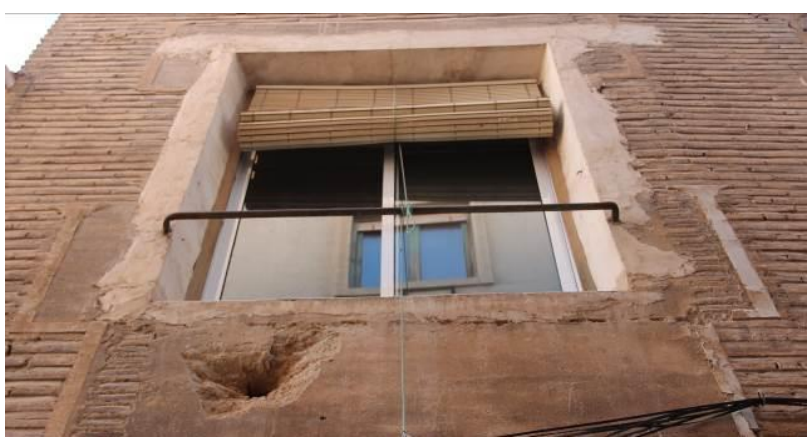

Figure 16. Mixed rammed earth wall on calle Caño no. 17 (Source: authors).

\subsection{Technical particularities}

Most of the constructions executed present a plinth made of a material other than earth, normally stone. This solves two problems as it protects from damp, both due to capillarity and rain or splashing, while also serving as a resource to level the base of the wall on sloping terrain. In the simpler constructions these are masonry plinths with abundant mortar. However, in palaces or casonas these plinths are Almagra stone (red travertine). The stone is either quarried or reused from earlier constructions. This stone is not only used in plinths (Figure 13) but also in thresholds and exposed corners. However, in some corners not only stone is used but also other materials such as brick or rammed earth with brick facing (Figure 14).

Equally, some recently demolished walls studied reveal wooden reinforcements inside, generally round logs placed longitudinally as distributing elements along the walls.

A clear distinction can be observed between the different walls of a single earthen building, closely linked to their structural function. Thus, mixed rammed earth walls, supplemented or with reinforcements, are used for load-bearing façades, while simple rammed earth walls are used in dividing walls.

In addition, in the walls of the Monasterio de la Encarnación and in various dwellings it is possible to see rammed earth and how it was used. First the brick pillar was built and then the formwork placed against it. The formwork boards were joined by a wooden strip called barrote or barzón and nailed perpendicular to the boards. These left traces on the inside of the rammed earth wall. Once the brick pillar was finished the length of the overlap of the Formwork was determined by that of the barzón. Given that the imprints left by the formwork could become weak points, bricks were placed against the strip to reinforce the emerging corner so that the traces of the strips can be seen from the bricks, and one side is solid brick and the other is rammed earth reinforced with brick. Normally, the trace of these strips can only be seen at one end of the formwork as the other end was nailed to the other side of the formwork. Sometimes, cracks corresponding to this strip appear in one course while in the next course the crack appears on the other side, showing how the Formwork alternated between one course and another (López, 1999, 2009) (Figures 15 and 16).

In Mula, these are also observed in more modest buildings, which optimize all the means available. Thus, often the crusts do not completely cover the wall face, although they can be made out in each layer, especially at the ends of the rammed earth walls where they form a sort of small joint. 


\subsection{Relation between earth techniques, residential architecture and main areas of Mula}

From a detailed analysis of the results of the study relationships can be established between different earthen techniques, different residential typologies, their position and height.

As seen in figure 6 , in the upper part of the town which corresponds to mediaeval constructions, most residential buildings are simple rammed earth wall rendered after the Formwork was removed or rammed earth supplemented with lime or gypsum crusts. Mixed rammed earth is a technique mostly used in the different areas of expansion of the city, both those of the 16th and of the 18th centuries, when the principal palaces or mansions were built. However, simple rammed earth walls can also be found in the lower part of the town, in humbler dwellings or secondary walls inside a single construction. The existence of dwellings which combine different rammed earth wall typologies depending on their structural function can also be observed.

In addition, the use of mixed rammed earth walls are also associated with larger, more important and more expensive constructions. As seen in table 1, humble dwellings represent $87 \%$ of the buildings studied: $31 \%$ were built using simple rammed earth walls, $49 \%$ with supplemented rammed earth walls, while only $20 \%$ were mixed rammed earth walls. Mansions or palaces account for $13 \%$ : $89 \%$ of these were built with mixed rammed earth and only $11 \%$ with supplemented rammed earth.

Another interesting result is the relationship between the height of constructions and the type of rammed earth technique used, as shown in table 2. Single-storey dwellings included in the study were humble dwellings built with simple rammed earth walls $(50 \%)$ or rammed earth with supplements on the exterior (50\%). However, higher buildings, with two or even three storeys are mostly built in supplemented or mixed rammed earth.

\begin{tabular}{l|cc} 
& \multicolumn{2}{|c}{ Residential architecture } \\
\hline $\begin{array}{l}\text { Earthen construction } \\
\text { typologies }\end{array}$ & Dwelling & Palace \\
$\quad$ Simple rammed earth & 19 & - \\
$\quad \begin{array}{l}\text { Supplemented rammed } \\
\text { earth }\end{array}$ & 30 & 1 \\
Mixed rammed earth & 12 & 8 \\
$\quad$ Dug-out architecture & 1 & -
\end{tabular}

Table 1. The relation between the earthen construction typologies and residential architecture.

\begin{tabular}{l|cccc} 
& \multicolumn{5}{|c}{ Number of floors } \\
\hline $\begin{array}{l}\text { Earthen construction } \\
\text { typologies }\end{array}$ & GF & GF+1 & GF+2 & GF+3 \\
$\quad$ Simple rammed earth & 3 & 15 & 1 & - \\
$\quad \begin{array}{l}\text { Supplemented rammed } \\
\text { earth }\end{array}$ & 3 & 19 & 8 & 1 \\
$\quad \begin{array}{l}\text { Mixed rammed earth } \\
\text { Dug-out architecture }\end{array}$ & - & 7 & 10 & 3 \\
$\quad$ & 1 & - & - & -
\end{tabular}

Table 2. The relation between earthen construction typologies and building elevation.

\subsection{State of conservation}

The partially missing or detached original renderings applied to the rammed earth walls have made it possible to quickly and easily identify the types of earthen construction in the numerous buildings analysed in this study. However, many others could not be included despite displaying features characteristic of rammed earth walls (thick walls and small openings) as their specific typology was almost impossible to determine. Equally, most of them present lesions due to years of dereliction, while lack of maintenance has accelerated their deterioration.

Nevertheless, it should be noted that varying degrees of repairs have also been carried out on the rammed earth walls in other cases. In this regard, the most frequently used technique consisted in the application of a thick layer of cement mortar to cover possible detachments from the surface. However, different solutions were used for larger surface losses on the section of the wall: from thick gypsum rendering with large stones to try to increase the bond between both elements, to an external layer of modern flat hollow brick (Figure 17).

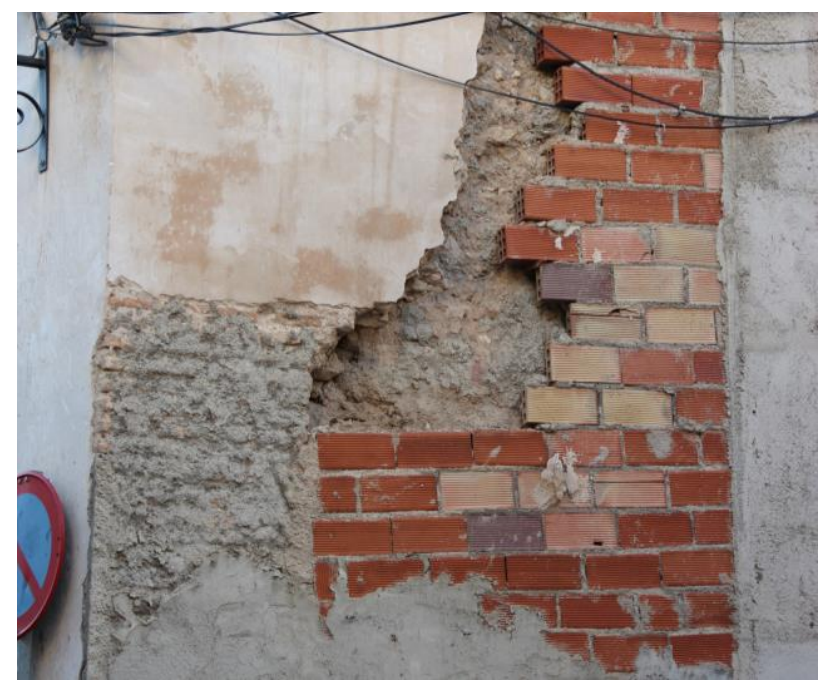

Figure 17. Hollow brick layer added to a rammed earth wall (Source: authors).

\section{CONCLUSIONS}

Following this study it is concluded that as well as the castle, many of the historic buildings in Mula were built in earth until approximately the 18 th century.

In addition, there are differences in construction between the types of technique used for rammed earth walls, and different types of building and construction periods. Simple rammed earth walls are most characteristic of the more modest homes, which tend to be located higher up in the city, while mixed rammed earth walls are frequently found in the Baroque palaces of Mula. There is thus a correlation between the importance of the building and the earthen construction technique used. Equally, there is also a significant relation between the total height of the buildings and the type of rammed earth construction used.

Moreover, it should be stressed that the results presented in this article are simply an initial examination of the vast range of construction solutions mainly using earth, found in the city of Mula. The cases analysed highlight the need for further study of 
all the residential buildings in the historic town centre, one which would include all the traditional dwellings in the historic centre in Mula. There should also be specific research on the cave dwellings, both their peculiarities and their links with similar dwellings in Spain and the rest of the world. Equally, there should be a record of the main lesions found in earthen architecture in Mula, analysing the various interventions which have been carried out to repair them, as well as chemical and mineralogical research to identify the materials in the rammed earth walls. Finally, it would be interesting to recognize any technical singularities designed to tackle the natural risks affecting the region, especially the earthquakes which have affected it over the years.

\section{ACKNOWDLEGEMENTS}

This work is part of the research project "RISK-Terra. Earthen architecture in the Iberian Peninsula: study of natural, social and anthropic risks and strategies to improve resilience", funded by the Spanish Ministry of Science, Innovation and Universities (Ref.:RTI2018-095302-B-I00; main researchers: Camilla Mileto and Fernando Vegas López-Manzanares).

\section{REFERENCES}

Collado Espejo, P. E., García León, J., La Spina, V., Fernández Del Toro, J., 2018: The islamic wall of Mula (Spain): 3D reconstruction, restoration and musealization. Vernacular and Earthen Architecture: Conservation and Sustainability. Taylor \& Francis Group, London, 429-434.

Fernández Del Toro, J., 2018: La Torre del Reloj de Mula. Ayuntamiento de Mula, Mula.

González Castaño, J. 1983: El Apocalipsis en Mula en la primavera de 1648. Revista Áreas, 3-4. Editora Regional de Murcia, Murcia, 181-191.

González Castaño, J., 1990: Síntesis de la historia de la ciudad de Mula. Caja de Ahorros del Mediterráneo, Mula.

González Castaño, J., González Fernández, R., 2005: Mula. Repertorio Heráldico. Universidad de Murcia, Murcia.

González Fernández, R., Fernández Matallana, F., 2010: Mula: el final de una ciudad de la Cora de Tudmir. PYRENAE 41(2), 81-119.

González Castaño, J., 1992: Una villa del Reino de Murcia en la Edad Moderna (Mula, 1500-1648). Real Academia Alfonso X el Sabio, Mula.

La Spina, V., Grau Giménez, C. J., 2020. Uses of Gypsum in Spanish architectural heritage: Typologies and some unique construction techniques. International Journal of Architectural Heritage, 14(2), 176-195.

López Martínez, F. J., 1999. Tapias y tapiales. Loggia. Arquitectura \& Restauración, 8,74-118.

López Martínez, F. J., 2009. Tapial, tapia y tapiería: propuesta de definición y clasificación. Mediterra 2009, Edicom Edizioni, Cagliari.
Mileto, C., Vegas, F., Cristini, V., 2011a: Earthen Architecture in Spain. Terra Europae. Earthen Architecture in European Union, ETS Ed., Pisa, 181-183.

Mileto, C., Vegas F., Cristini, V., García Soriano, L., 2011 b. Earthen techniques in Europe. Terra Europae. Earthen Architecture in European Union, ETS Ed., Pisa, p. 195-202.

Mileto, C., Vegas F., Cristini, V., 2012. Refuerzos y mejoras: variantes constructivas de la tapia en España. Terra 2012. XI Conferencia Internacional sobre el Estudio y Conservación del Patrimonio Arquitectónico de Tierra, 10-20.

Mileto C., Vegas, F., Cristini, V., García Soriano, L., 2014: La tapia en la Península Ibérica. La restauración de la arquitectura de tapia en la Península Ibérica. TC Cuadernos / Argumentum. Valencia / Lisboa, 32-51.

Molina López, E. 1995: Aproximación al estudio de Mula islámica. Ayuntamiento de Mula, Mula.

Ródenas Cañada, J. M., 1991: Guía de arquitectura de Mula, Colegio Oficial de Arquitectos, Murcia.

Soler Huertas, B. 2005. El travertino rojo de Mula (Murcia). Definición de un marmol local. Verdolay: Revista del Museo Arqueológico de Murcia 9, 1361-1370.

VVAA (Bestué Cardiel, I.), 2018: Plan Director del Castillo de Mula (Murcia). Ayuntamiento de Mula. 